\title{
SHC-Transforming Protein 1
}

National Cancer Institute

\section{Source}

National Cancer Institute. SHC-Transforming Protein 1. NCI Thesaurus. Code C29946.

SHC-transforming protein 1 (583 aa, $\sim 63 \mathrm{kDa}$ ) is encoded by the human SHC1 gene. This protein plays a role in coupling growth factor receptors to downstream signaling proteins. 